\title{
Cochrane
}

Library

Cochrane Database of Systematic Reviews

\section{EMG biofeedback for the recovery of motor function after stroke} (Review)

Woodford HJ, Price CIM

Woodford HJ, Price CIM.

EMG biofeedback for the recovery of motor function after stroke.

Cochrane Database of Systematic Reviews 2007, Issue 2. Art. No.: CD004585.

DOI: 10.1002/14651858.CD004585.pub2.

www.cochranelibrary.com 
TABLE OF CONTENTS

ABSTRAC

PLAIN LANGUAGE SUMMARY

BACKGROUND

OBJECTIVES

METHODS

RESULTS

DISCUSSION

AUTHORS' CONCLUSIONS

ACKNOWLEDGEMENTS

REFERENCES

CHARACTERISTICS OF STUDIES

DATA AND ANALYSES

Analysis 1.1. Comparison 1 Electromyographic biofeedback plus physical therapy versus physical therapy alone, Outcome 1 Change in motor strength (MRC scale).

Analysis 1.2. Comparison 1 Electromyographic biofeedback plus physical therapy versus physical therapy alone, Outcome 2 Change in range of motion.

Analysis 1.3. Comparison 1 Electromyographic biofeedback plus physical therapy versus physical therapy alone, Outcome 3 Change in stride length.

Analysis 1.4. Comparison 1 Electromyographic biofeedback plus physical therapy versus physical therapy alone, Outcome 4 Change in gait speed.

Analysis 1.5. Comparison 1 Electromyographic biofeedback plus physical therapy versus physical therapy alone, Outcome 5 Changes in functional ability.

Analysis 1.6. Comparison 1 Electromyographic biofeedback plus physical therapy versus physical therapy alone, Outcome 6 Change in gait quality score.

Analysis 1.7. Comparison 1 Electromyographic biofeedback plus physical therapy versus physical therapy alone, Outcome 7 Sham EMG-BFB versus no placebo: range of motion at ankle joint.

Analysis 1.8. Comparison 1 Electromyographic biofeedback plus physical therapy versus physical therapy alone, Outcome 8

Time from stroke and change in range of movement at ankle.

APPENDICES

WHAT'S NEW

CONTRIBUTIONS OF AUTHORS

DECLARATIONS OF INTEREST

INDEX TERMS 
[Intervention Review]

\section{EMG biofeedback for the recovery of motor function after stroke}

Henry J Woodford ${ }^{1}$, Christopher IM Price ${ }^{2}$

1Elderly Medicine, Cumberland Infirmary, Carlisle, UK. 2Elderly Services, Northumbria Healthcare NHS Trust, Ashington, UK

Contact: Henry J Woodford, Elderly Medicine, Cumberland Infirmary, Newtown Road, Carlisle, Cumbria, CA2 7HY, UK.

henry.woodford@ncumbria-acute.nhs.uk.

Editorial group: Cochrane Stroke Group.

Publication status and date: Edited (no change to conclusions), published in Issue 1, 2010.

Citation: Woodford HJ, Price CIM. EMG biofeedback for the recovery of motor function after stroke. Cochrane Database of Systematic Reviews 2007, Issue 2. Art. No.: CD004585. DOI: 10.1002/14651858.CD004585.pub2.

Copyright @ 2010 The Cochrane Collaboration. Published by John Wiley \& Sons, Ltd.

\section{A B S T R A C T}

\section{Background}

Electromyographic biofeedback (EMG-BFB) is a technique that is believed to have additional benefit when used with standard physiotherapy for the recovery of motor function in stroke patients. However, evidence from individual trials and previous systematic reviews has been inconclusive.

\section{Objectives}

To assess the effects of EMG-BFB for motor function recovery following stroke.

\section{Search methods}

We searched the Cochrane Stroke Group Trials Register (last searched 30 March 2006), the Cochrane Central Register of Controlled Trials (CENTRAL) (The Cochrane Library Issue 4, 2005), MEDLINE (1966 to November 2005), EMBASE (1980 to November 2005), CINAHL (1983 to November 2005), PsycINFO (1974 to November 2005) and First Search (1966 to November 2005). We scanned reference lists for relevant articles and contacted equipment manufacturers and distributors.

\section{Selection criteria}

Randomised and quasi-randomised studies comparing EMG-BFB with control for motor function recovery in stroke patients.

\section{Data collection and analysis}

Two review authors independently assessed trial quality and extracted data. Where possible we contacted study authors for further information. Any reported adverse effects were noted.

\section{Main results}

Thirteen trials involving 269 people were included. All trials compared EMG-BFB plus standard physiotherapy to standard physiotherapy either alone or with sham EMG-BFB. Only one study used a motor strength assessment scale for evaluation of patients, which indicated benefit from EMG-BFB (WMD 1.09, 95\% $\mathrm{Cl} 0.48$ to 1.70). EMG-BFB did not have a significant benefit in improving range of motion (ROM) through the ankle (SMD $0.05,95 \% \mathrm{Cl}-0.36$ to 0.46 ), knee or wrist joints. However, one trial suggested a benefit in ROM at the shoulder (SMD $0.88,95 \% \mathrm{Cl} 0.07$ to 1.70 ). Change in stride length or gait speed was not improved by EMG-BFB. Two studies used different assessment scores to quantify gait quality. One of these suggested a beneficial effect of EMG-BFB (SMD $0.90,95 \% \mathrm{Cl} 0.01$ to 1.78 ). Most of the studies examining functional outcomes used different assessment scales, which made meta-analysis impossible. Two studies that used the same scale did show a beneficial effect (SMD 0.69, $95 \% \mathrm{Cl} 0.15$ to 1.23 ). 


\section{Authors' conclusions}

Despite evidence from a small number of individual studies to suggest that EMG-BFB plus standard physiotherapy produces improvements in motor power, functional recovery and gait quality when compared to standard physiotherapy alone, combination of all the identified studies did not find a treatment benefit. Overall the results are limited because the trials were small, generally poorly designed and utilised varying outcome measures.

\section{PLAIN LANGUAGE SUMMARY}

\section{EMG biofeedback for the recovery of motor function after stroke}

Electromyographic biofeedback (techniques using visual or sound signals to monitor muscle activity) has an uncertain impact on recovery after stroke. Electromyographic biofeedback (EMG-BFB) uses electrodes placed on a patient's muscles to generate a feedback signal (in vision or sound) in response to muscle activation. It is believed that this may allow patients to learn a more effective way of using their disabled limb. Amongst the 13 studies identified, there was a small amount of evidence to suggest that EMG-BFB had a beneficial effect when used with standard physiotherapy techniques. However EMG-BFB cannot currently be recommended as an effective routine treatment because other studies found no effect, and the positive trials were small. 


\section{B A C K G R O U N D}

Stroke is a major cause of disability. There are an estimated nine million stroke survivors worldwide per year and this figure is predicted to rise 30\% between the years 1983 and 2023 (Wolfe 2000). Around one third of those alive at six months following a stroke are functionally dependent on others (Warlow 1998). To date, the major management of most strokes remains rehabilitation and secondary prevention. Any technique that could enable a more rapid or complete functional recovery would have major benefits both in terms of patients' well-being and health economics.

Biofeedback (BFB) has been used in rehabilitation for over 40 years (De Weerdt 1985). The technique tries to transduce a physiological electrical response, which would normally be subliminal, into an auditory or visual stimulus to the patient. In terms of motor function recovery this is normally in the form of an electromyogram (EMG). This records a difference in potential along the length of a muscle using electrodes over the skin surface. After amplification, the signal is displayed in a simplified format to the patient, for example, by hearing a change in auditory tone or by seeing a response on an oscilloscope display (De Weerdt 1986a).

The theory is that, following a stroke, the normal regulation of muscle tone is disrupted by neuronal damage, which leads to both inappropriate decreases and increases (spasticity) in muscular activity. It is proposed that the patient may have some unaffected pathways preserved but that these may not be initially obvious (Glanz 1997). By using electromyogram biofeedback (EMG-BFB) it may be possible for individuals to learn how to use these preserved pathways. They may then be able to control muscular activity in order to recover motor function following a stroke.

Despite its continuing use in rehabilitation, there remains doubt over the efficacy of this technique. EMG-BFB is referenced within the Royal College of Physicians' guidelines on stroke (RCPstroke 2004), concluding that there is currently no evidence of advantage over traditional therapy. A previous recommendation in favour of its use has been withdrawn. A number of review articles have not found clear evidence of benefit (De Weerdt 1986b; Glanz 1995; Glanz 1997; Moreland 1998; Schleenbaker 1993).

\section{O B J E C T IVES}

The specific objective of this review was to determine the efficacy of any form of EMG-BFB used after a stroke in order to aid motor function recovery.

\section{METHODS}

\section{Criteria for considering studies for this review}

\section{Types of studies}

We considered all randomised controlled trials (RCTs) and quasirandomised controlled trials comparing EMG-BFB with no EMG BFB or sham EMG-BFB. We contacted individual trialists, where necessary, in cases where treatment allocation was uncertain. We noted blinding of outcome assessment, but did not use this to exclude trials. We did not consider it essential that the control group received a sham treatment, but we noted any placebo.

\section{Types of participants}

We considered trials that included patients of any age or gender with a clinical diagnosis of stroke, with or without a computerised tomography (CT) scan. We did not use previous stroke as a basis for exclusion. We did not identify any otherwise suitable trials that included a mixed group of subjects with other causes for their neurological injury. No predetermined time limit was set for how soon after stroke the EMG-BFB technique was performed.

\section{Types of interventions}

We used the study authors' definitions of EMG-BFB. Techniques were expected to involve electrodes being placed on the skin surface above the muscle group being tested, with the electrical activity displayed to the patient in either a visual or auditory format. We recorded all variations in the muscle groups used, forms of biofeedback undertaken and duration of therapy to the recipient. We excluded studies which had EMG-BFB as only one part of a multiple intervention package (e.g. EMG-BFB plus electrical stimulation versus control) unless the results of the studies recorded the outcome data separately for the individual interventions.

\section{Types of outcome measures}

We extracted six types of outcome data from identified trials to allow an intention-to-treat analysis. The primary outcome measure was the change in muscle power relative to baseline in the intervention and control groups. The five secondary outcomes were:

- the change in range of motion through a specified joint (degrees) relative to baseline in intervention and control groups;

- improvement in gait, measured by changes in stride length (centimetres) or speed (seconds) and changes in needs for ambulation aids relative to baseline in intervention and control groups;

- the change in function ability relative to baseline in intervention and control groups;

- the change in electromyographic activity relative to the baseline recording;

- the proportion of subjects with muscle weakness due to stroke in treatment and control groups.

We did not include studies which only reported EMG activity as an outcome. EMG potentials alone have no direct functional significance, there is a wide variation in calibration, and as different authors average their values, the absolute readings are not directly comparable.

\section{Search methods for identification of studies}

See: 'Specialized register' section in Cochrane Stroke Group

We searched the Cochrane Stroke Group Trials Register, which was last searched by the Review Group Co-ordinator on 30 March 2006. In addition, we searched the Cochrane Central Register of Controlled Trials (CENTRAL) (The Cochrane Library Issue 4, 2005), MEDLINE (January 1966 to November 2005), EMBASE (January 1980 to November 2005), First Search (January 1966 to November 2005), CINAHL (January 1983 to November 2005) and PsycINFO (January 1974 to November 2005) (Appendix 1). 
In an attempt to identify further published, unpublished and ongoing trials, we scanned reference lists of relevant articles and contacted equipment manufacturers and distributors (Thought Technology Limited and Bio-Medical Instruments). Articles published in languages other than English were translated.

\section{Data collection and analysis}

Two independent review authors with a background in stroke rehabilitation medicine screened the titles and abstracts of articles identified by the electronic searches. They decided which trials met the inclusion criteria, and judged their methodological quality. Allocation concealment before randomisation was scored using The Cochrane Collaboration's grading system: A - adequate; B - unclear; C - inadequate; or D - not used. We used checklists to independently record details of the randomisation method, study population, EMG methods employed, length of follow up, and outcome measures. We carefully noted the proportions of participants that completed the intervention period, and reasons why they left the study prematurely. Analysis was by intention to treat. Extracted data were checked for agreement between review authors. We attempted to contact trialists to request missing data.

We calculated a weighted treatment effect for each of the outcome measures. Outcomes were combined using the weighted mean difference (WMD) for identical measures, and standardised mean difference (SMD) for different measures. Where there was obvious variation between the WMD or SMD of individual studies ( $P$ value $<$ 0.1 ), a random-effects model was applied.

Motor function after stroke has been recorded by a variety of clinical rating scales such as the Medical Research Council scale. It has also been measured directly by force transduction devices. A number of functional assessment tools have been utilised, such as the upper extremity functional test (UEFT), the action research arm test (ARA), and the Nottingham 10 point activities of daily living (ADL) scale. It is not clear which method is best. Therefore, the results should be interpreted with some caution, and the reliability of such measures will be left to the judgement of readers of this review. We recorded length of follow up, and noted whether assessors were blinded to treatment allocation. We reported attrition rates if known.

We planned sensitivity analyses a priori for studies that had the following characteristics:

- true randomised versus quasi-randomised;

- blinded versus unblinded treatment;

- blinded versus unblinded outcome measurement;

- placebo (sham treatment) versus none;

- time after stroke before use of EMG biofeedback technique.

\section{RESULTS}

\section{Description of studies}

The search strategy outlined above identified 23 RCTs utilising EMG$B F B$ in the rehabilitation of stroke patients. Ten of these were excluded from the analysis for a combination of the following reasons: insufficient raw data, despite attempts to contact the authors (Basmajian 1982; Ince 1987; Mandel 1990; Olney 1997; Prevo 1982; Shahani 1977; Taskiran 1993; Wolf 1994); the use of a cross-over design without the capacity to extract data after the first intervention period (Chen 1980); and inability to obtain the original article (Ince 1991). Thirteen studies, involving 269 patients (mean number per study $=21$, range 9 to 40 ), were included in the analysis (Armagan 2003; Basmajian 1987; Binder 1981; Bradley 1998; Burnside 1982; Cozean 1988; Crow 1989; Inglis 1984; Intiso 1994; Lee 1985; Mroczek 1978; Mulder 1986; Smith 1979).

From the studies that stated values, the mean age of subjects was 62 years (range 52 to 70 ), and the mean percentage of males was 62 (range $45 \%$ to $81 \%$ ). It is worth noting that there was a very wide variation between studies for the time from the stroke to randomisation (mean time 255 days; range 35 to 1140 days). The duration of studies ranged form four to 16 weeks, with a six-week intervention period being most common. All participants had a residual weakness of either the upper or lower limb. Insufficient cognitive capacity to participate in the program, including receptive dysphasia, was a common reason for patient exclusion. There was a wide variation in the outcome measures used. None of the included studies used EMG potentials alone as an outcome assessment.

The studies had different time intervals between the intervention period and later outcome measures, so only the readings taken at the end of the intervention period were included.

\section{Risk of bias in included studies}

Details of the included studies are shown in the 'Characteristics of included studies' table. Reliable randomisation was described in only one study (Armagan 2003), which was by numbered envelopes. Four studies used quasi-randomised methods (Basmajian 1987; Burnside 1982; Crow 1989; Mroczek 1978). A sham form of EMG-BFB (the machine attached but either switched off or not visible to the patient) was used in two studies (Armagan 2003; Burnside 1982). In one study randomisation was not mentioned at all (Intiso 1994). Given the small number of suitable studies identified, this has still been included as the presentation of results suggests at least quasirandomisation.

In all studies that specified within their methods, assessment was performed by an individual blinded to the patients' treatments. No adverse events relating to interventions were reported in any study. Two studies reported sub-optimal completion rates. In one, two patients in the control group died (Bradley 1998), in another two patients in the control group were withdrawn due to a further stroke and a fractured neck of femur (Intiso 1994). The data from these four patients were not included in the subsequent analyses.

\section{Effects of interventions}

\section{Comparison 1.1: Change in motor strength}

Although initially identified as the primary outcome prior to the search, only one study used a motor strength assessment (the Medical Research Council scale). Of course, this makes metaanalysis impossible. However, the result of this study was positive for a benefit of EMG-BFB (weighted mean difference (WMD) 1.09, $95 \%$ confidence interval ( $\mathrm{Cl}) 0.48$ to 1.70 ).

\section{Comparison 1.2: Change in range of motion}

Eight trials used the range of motion (ROM) through a joint as an outcome measure: five at the ankle, and one each for the shoulder, wrist, and knee. A combination of results from studies assessing ankle ROM, including a total of 91 patients, did not demonstrate a significant effect of EMG-BFB (standardised mean difference (SMD) $0.05,95 \% \mathrm{Cl}-0.36$ to 0.46 ), nor did individual trial results for the 
knee or wrist. However, the only trial assessing ROM at the shoulder did suggest a beneficial effect (SMD $0.88,95 \% \mathrm{Cl} 0.07$ to 1.70 ).

\section{Comparison 1.3: Change in stride length}

Two studies calculated the number of steps taken to walk a specified distance ( 6 or 10 metres). Two studies measured stride length before and after the intervention period. None of the results alone reached significance. The differing outcome measures made meta-analysis impossible.

\section{Comparison 1.4: Change in gait speed}

Three studies measured the time taken to walk a specified distance (6, 10 or 50 metres). A further study measured gait cycle time, and another measured walking velocity. The combined result of the three studies assessing time over a specified distance did not show a significant effect (SMD $0.13,95 \% \mathrm{Cl}-0.55$ to 0.80 ). None of the other studies demonstrate a significant benefit with EMG-BFB.

\section{Comparison 1.5: Changes in functional ability}

Six studies incorporated functional outcome measures into the patient assessments. Two of these studies used more than one functional measure. For the purposes of this review, only one measure was included from each study. Unfortunately only two of the studies used the same assessment scales as each other. A combination of the results for change in Brunnstrom Stages of Recovery scores did show a significant effect (SMD 0.69, 95\% Cl 0.15 to 1.23$)$. Individual trial results did not demonstrate a significant effect.

\section{Comparison 1.6: Change in gait quality score}

Two studies used different assessment scores to quantify gait quality. One of these suggested a small positive effect of EMG-BFB compared to controls (SMD $0.90,95 \% \mathrm{Cl} 0.01$ to 1.78 ).

Sensitivity analyses were only possible for comparison of change in range of ankle motion between groups that had a sham intervention versus no placebo, and between those studies with a time interval of less than or more than six months after onset of stroke. There was only one study that used a sham intervention, and that showed no significant difference compared to no placebo. The comparison between groups less than or more than six months from stroke onset did not reveal any significant difference in outcomes.

\section{DISCUSSION}

Despite several decades of EMG-BFB use in stroke rehabilitation, a randomised trial recruiting over 40 patients has not been performed. The small sample sizes make it possible for a positive treatment effect to have been missed, even after combination of studies. Statistical combination of studies is also hampered by the different outcome measures used in each. Some studies could not be included due to the inadequate publication of raw data in original articles, the inability to contact authors, and the loss of data (mainly due to the long time periods that have passed since the studies were done).

Overall, the data available do not demonstrate an effect of EMG$B F B$ in the restoration of ROM through a specified joint, functional ability scales, or in improvements in stride length or gait speed following a disabling stroke. However, there is some evidence from individual trials of improvements in gait quality assessments, ROM at the shoulder and restoration of motor power. In addition, when combined, two trials suggested a benefit in a functional recovery score. It would seem reasonable to expect that improvements in motor power would lead to an increase in ROM at a joint, and that improved gait quality should result in improved gait speed and stride length. The discrepancy between the findings is physiologically inconsistent.

The reasons for study outcome variance may be related to the small numbers of participants and short time periods used in the studies. Also, the trials vary in the time from stroke to randomisation. However, the trials showing benefit in motor power and gait quality scores had the longest mean time interval from stroke (Burnside 1982; Smith 1979), yet the trials demonstrating benefit in functional assessment scales included those with the shortest time interval (Bradley 1998; Crow 1989). This analysis is not able to assess whether the observed benefits are maintained or tend to reduce over time.

\section{AUTHORS' CONCLUSIONS}

\section{Implications for practice}

When all the available data are combined, EMG-BFB does not appear to have any positive benefit for recovery after stroke. It cannot be recommended as a routine treatment. A small amount of evidence from individual studies suggests that using EMG-BFB in combination with standard physiotherapy regimes may result in improvements in motor power, ROM at the shoulder, functional recovery and gait quality beyond those of standard physiotherapy alone. As there were no reported adverse effects, it would seem reasonable for EMG-BFB to be considered as a cautious treatment approach for individual patients whose circumstances match the inclusion criteria of the studies included in this review.

\section{Implications for research}

There is need for a randomised clinical trial with adequate power, using standardised assessment scales and robust adverse event reporting, to assess the effectiveness of EMG-BFB.

\section{ACKN OWLEDGEMEN TS}

None 


\section{RE F E R E N C E S}

\section{References to studies included in this review}

Armagan 2003 \{published data only\}

Armagan O, Tascioglu F, Oner C. Electromyographic biofeedback in the treatment of the hemiplegic hand: a placebo-controlled study. American Journal of Physical and Medical Rehabilitation 2003;82(11):856-61.

\section{Basmajian 1987 \{published data only\}}

Basmajian JV, Gowland CA, Finlayson AJ, Hall AL, Swanson LR, Stratford PW, et al. Stroke treatment: comparison of integrated behavioural-physical therapy vs traditional physical therapy programs. Archives of Physical Medicine and Rehabilitation 1987;68:267-72.

\section{Binder 1981 \{published data only\}}

Binder S, Moll CB, Wolf SL. Evaluation of electromyographic biofeedback as an adjunct to therapeutic exercise in treating the lower extremities of hemiplegic patients. Physical Therapy 1981;61(6):886-93.

\section{Bradley 1998 \{published data only\}}

Bradley L, Hart BB, Mandana S, Flowers K, Riches M, Sanderson P. Electromyographic biofeedback for gait training after stroke. Clinical Rehabilitation 1998;12:11-22.

\section{Burnside 1982 \{published data only\}}

Burnside IG, Tobias HS, Bursill D. Electromyographic feedback in the remobilization of stroke patients: a controlled trial. Archives of Physical Medicine and Rehabilitation 1982;63:217-22.

Cozean 1988 \{published data only\}

Cozean CD, Pease WS, Hubbell SL. Biofeedback and functional electrical stimulation in stroke rehabilitation. Archives of Physical Medicine and Rehabilitation 1988;69:401-5.

\section{Crow 1989 \{published data only\}}

Crow JL, Lincoln NB, Nouri FM, de Weerdt W. The effectiveness of EMG biofeedback in the treatment of arm function after stroke. International Disability Studies 1989;11(4):155-60.

Inglis 1984 \{published data only\}

Inglis J, Donald MW, Monga TN, Sproule M, Young MJ. Electromyographic biofeedback and physical therapy of the hemiplegic upper limb. Archives of Physical Medicine and Rehabilitation 1984;65:755-9.

Intiso 1994 \{published data only\} Intiso D, Santilli V, Grasso MG, Rossi R, Caruso I. Rehabilitation of walking with electromyographic biofeedback in foot-drop after stroke. Stroke 1994;25(6):1189-92.

Lee 1985 \{published data only\}

Lee SJ, Ahn YP. Clinical effect of electromyographic biofeedback treatment in hemiplegic patients. Journal of the Catholic Medical College 1985;38(1):387-94.
Mroczek 1978 \{published data only\}

Mroczek N, Halpern D, McHugh R. Electromyographic feedback and physical therapy for neuromuscular retraining in hemiplegia. Archives of Physical Medicine and Rehabilitation 1978;59:258-67.

\section{Mulder 1986 \{published data only\}}

Mulder T, Hulstijn W, van der Meer J. EMG feedback and the restoration of motor control: a controlled group study of 12 hemiparetic patients. American Journal of Physical Medicine 1986;65(4):173-88.

Smith 1979 \{published data only\}

Smith K. Biofeedback in strokes. Australian Journal of Physiotherapy 1979;25(4):155-61.

\section{References to studies excluded from this review}

Basmajian 1982 \{published data only\}

Basmajian JV, Gowland CA, Brandstater ME, Swanson LR, Trotter JE. EMG feedback treatment of upper limb hemiplegic stroke patients: a pilot study. Archives of Physical Medicine and Rehabilitation 1982;63:613-6.

Chen 1980 \{published data only\}

Chen H, Chu M, Sung M. Electromyographic biofeedback treatment in hemiplegia. Chinese Medical Journal 1980;27(3):557-61.

Ince 1987 \{published data only\}

Ince LP, Zaretsky HH, Lee MHM, Kerman-Lerner P, Adler J. Integrating EMG biofeedback treatment of the impaired upper extremity into the rehabilitation programs of stroke patients. Archives of Physical Medicine and Rehabilitation 1987;68:645.

Ince 1991 \{published data only\}

Ince LP, Jette CB, Zaretsky HH, Lee MH. Biofeedback: an integrated rehabilitation modality for restoration of upper extremity function in stroke patients. Medical Psychotherapy 1991;4:95-103.

\section{Mandel 1990 \{published data only\}}

Mandel AR, Nymark JR, Balmer SJ, Grinnell DM, O'Riain MD. Electromyographic versus rhythmic positional biofeedback in computerized gait retraining with stroke patients. Archives of Physical Medicine and Rehabilitation 1990;71:649-54.

\section{Olney 1997 \{published data only\}}

Olney S, Nymark J, Zee B, Martin C, Mcnamara P. Effects of computer assisted gait retraining (BioTRAC) in early stroke: a randomised clinical trial. Journal of Stroke and Cerebrovascular Disorders 1997;6:457.

\section{Prevo 1982 \{published data only\}}

Prevo AJH, Visser SL, Vogelaar TW. Effect of EMG feedback on paretic muscles and abnormal co-contraction in the hemiplegic arm, compared with conventional physiotherapy. Scandinavian Journal of Rehabilitation Medicine 1982;14:121-31. 
Shahani 1977 \{published data only\}

Shahani BT, Connors L, Mohr JP. Electromyographic audiovisual feedback training effect on the motor performance in patients with lesions of the central nervous system. Archives of Physical Medicine and Rehabilitation 1977;58:519.

Taskiran 1993 \{published data only\}

Tasikran FH. The effect of EMG biofeedback for the stabilization of the ankle in the hemiplegic patients [Hemiplejik hastalarda ayak bilegi stabilizasyonunun saglanmasinda EMG biofeedback in etkinligi]. Istanbul Tip Fakultesi Mecmuaya 1993;56(4):49-52.

Wolf 1994 \{published data only\}

Wolf SL, Catlin PA, Blanton S, Edelman J, Lehrer N, Schroeder D. Overcoming limitations in elbow movement in the presence of antagonist hyperactivity. Physical Therapy 1994;74(9):826-35.

\section{Additional references}

\section{De Weerdt 1985}

De Weerdt WJG, Harrison MA. The use of biofeedback in physiotherapy. Physiotherapy 1985;71(1):9-12.

\section{De Weerdt 1986a}

De Weerdt WJG, Harrison MA. Electromyographic biofeedback for stroke patients: some practical considerations. Physiotherapy 1986;72(2):106-8.

\section{De Weerdt 1986b}

De Weerdt WJG, Harrison MA. The efficacy of electromyographic feedback for stroke patients: a critical review of the main literature. Physiotherapy 1986;72(2):108-18.

\section{CHARACTERISTICS OF STUDIES}

Characteristics of included studies [ordered by study ID]

\section{Glanz 1995}

Glanz M, Klawansky S, Stason W, Berkey C, Shah N, Phan H, et al. Biofeedback therapy in poststroke rehabilitation: a metaanalysis of the randomised controlled trials. Archives of Physical Medicine and Rehabilitation 1995;76:508-15.

\section{Glanz 1997}

Glanz M, Klawansky S, Chalmers T. Biofeedback therapy in stroke rehabilitation: a review. Journal of the Royal Society of Medicine 1997;90:33-9.

\section{Moreland 1998}

Moreland JD, Thompson MA, Fuoco AR. Electromyographic biofeedback to improve lower extremity function after stroke: a meta-analysis. Archives of Physical Medicine and Rehabilitation 1998;79:134-40.

\section{RCPstroke 2004}

National Clinical Guidelines for Stroke: Update 2004. http://www.rcplondon.ac.uk/pubs/books/stroke/ StrokeUpdate2004.pdf 2004.

\section{Schleenbaker 1993}

Schleenbaker RE, Mainous AG. Electromyographic biofeedback for neuromuscular reeducation in the hemiplegic stroke patient: a meta-analysis. Archives of Physical Medicine and Rehabilitation 1993;74:1301-4.

\section{Warlow 1998}

Warlow CP. Epidemiology of stroke. Lancet 1998;352 (Suppl III):1-4.

\section{Wolfe 2000}

Wolfe CDA. The impact of stroke. British Medical Bulletin 2000;56(2):275-86

Armagan 2003

\begin{tabular}{|c|c|}
\hline Methods & $\begin{array}{l}\text { RCT of 4-week duration } \\
\text { Randomisation by numbered envelopes } \\
\text { Assessments by a blinded evaluator }\end{array}$ \\
\hline Participants & $\begin{array}{l}27 \text { participants ( } 14 \text { intervention, } 13 \text { control) } \\
\text { Mean age } 57 \text { years (range } 39 \text { to } 77 \text { years) } \\
\text { Mean time from stroke of } 4.6 \text { months (range } 3 \text { to } 6 \text { months) } \\
59 \% \text { male } \\
\text { Exclusions included significant cognitive impairment or limb spasticity, and previous physiotherapy or } \\
\text { EMG feedback therapy }\end{array}$ \\
\hline
\end{tabular}

Interventions

Exercise program plus EMG-BFB or exercise plus placebo EMG-BFB 20-minute sessions 5 times a week for 4 weeks

Outcomes

Brunstrom's Stages of Hand Recovery, a scale for judging drinking from a glass, active range of motion at wrist and EMG surface potentials 
Armagan 2003 (Continued)

\section{Risk of bias}

\begin{tabular}{lll}
\hline Bias & Authors' judgement & Support for judgement \\
\hline Allocation concealment? & Low risk & A - Adequate \\
\hline
\end{tabular}

Basmajian 1987

$\begin{array}{ll}\text { Methods } & \text { RCT of 5-week duration plus } 9 \text { month follow up } \\ \text { Randomisation method 'balanced' after every } 4 \text { patients and across strata } \\ \text { Assessments by a blinded evaluator }\end{array}$

\begin{tabular}{ll}
\hline Participants & $\begin{array}{l}\text { 29 participants (13 intervention, } 16 \text { control) } \\
\text { Mean age } 62 \text { years } \\
\text { Mean time from stroke } 16 \text { weeks } \\
66 \% \text { male }\end{array}$ \\
\hline Interventions & $\begin{array}{l}\text { Physiotherapy alone vs physiotherapy plus EMG-BFB } \\
\text { 45-minute sessions } 3 \text { times a week for } 5 \text { weeks }\end{array}$ \\
\hline Outcomes & $\begin{array}{l}\text { Upper Extremity Function Test } \\
\text { Finger Oscillation Test }\end{array}$ \\
\hline Notes &
\end{tabular}

\section{Risk of bias}

\begin{tabular}{lll}
\hline Bias & Authors' judgement & Support for judgement \\
\hline Allocation concealment? & High risk & C - Inadequate \\
\hline
\end{tabular}

Binder 1981

$\begin{array}{ll}\text { Methods } & \text { RCT of 4-week duration } \\ \text { Randomisation method that maintained equivalent numbers between groups } \\ \text { Assessments performed by a blinded evaluator }\end{array}$

Participants
Mean age unknown, at least 16 months from stroke event
\% male unknown
Patients with residual lower limb weakness but able to walk short distances

\begin{tabular}{ll}
\hline Interventions & Physiotherapy alone vs physiotherapy plus EMG-BFB \\
& 30 to 40 -minute treatment sessions 3 times a week for 4 weeks
\end{tabular}

Outcomes Active range of ankle movement

Time to walk 50 metres on both smooth and carpeted surfaces

\begin{tabular}{ll}
\hline Notes & \\
\hline Risk of bias & Authors' judgement Support for judgement
\end{tabular}


Binder 1981 (Continued)
Allocation concealment?
High risk
C - Inadequate

Bradley 1998

\begin{tabular}{|c|c|}
\hline Methods & $\begin{array}{l}\text { RCT of 6-week duration plus further } 12 \text { week follow up } \\
\text { Randomisation method not stated }\end{array}$ \\
\hline Participants & $\begin{array}{l}\text { Data available for a total of } 21 \text { participants ( } 12 \text { intervention, } 9 \text { control) } \\
\text { Mean age } 70 \text { years } \\
\text { Mean time from stroke } 36 \text { days }\end{array}$ \\
\hline Interventions & Physiotherapy plus EMG-BFB vs physiotherapy alone \\
\hline Outcomes & $\begin{array}{l}\text { Time taken and number of steps to do a } 10 \text { metre walk (but only } 14 \text { subjects able to perform) } \\
\text { Rivermead mobility index } \\
\text { Range of movement at ankle } \\
\text { Nottingham extended ADL index }\end{array}$ \\
\hline \multicolumn{2}{|l|}{ Notes } \\
\hline \multicolumn{2}{|l|}{ Risk of bias } \\
\hline Bias & Authors' judgement Support for judgement \\
\hline Allocation concealment? & Unclear risk \\
\hline
\end{tabular}

Burnside 1982

\begin{tabular}{ll} 
Methods & $\begin{array}{l}\text { RCT of 6-week duration with 12-week follow up } \\
\text { Groups matched on age, duration and initial strength } \\
\text { Assessments by a blinded evaluator }\end{array}$ \\
\hline Participants & 22 participants (11 in each group) \\
Mean age 70 years \\
Mean time from stroke of 4.8 years \\
46\% male \\
Patients at least 3 months from a stroke event and with residual lower limb weakness but able to walk \\
short distances
\end{tabular}

15-minute sessions twice a week for 6 weeks

\begin{tabular}{ll}
\hline Outcomes & $\begin{array}{l}\text { Muscle strength of tibialis anterior (MRC scale } 0 \text { to 5) } \\
\text { Active range of movement at ankle } \\
\text { Basmajian's rating scale for gait }\end{array}$ \\
\hline
\end{tabular}

Notes

\section{Risk of bias}

\begin{tabular}{lll}
\hline Bias & Authors' judgement & Support for judgement \\
\hline Allocation concealment? & High risk & C-Inadequate
\end{tabular}

EMG biofeedback for the recovery of motor function after stroke (Review) 
RCT of 6-week duration

Randomisation method not stated

Assessments by a blinded evaluator

1 drop out from each group

Comparison also made to functional electrical stimulation (data not included in this review)

\begin{tabular}{ll}
\hline Participants & $\begin{array}{l}\text { 16 participants (8 in each group) } \\
\text { Mean age 57 years } \\
\text { Mean time from stroke not stated } \\
63 \% \text { male } \\
\text { Sufficient cognitive capacity to participate and able to mobilise with the assistance of one therapist }\end{array}$ \\
\hline Interventions & $\begin{array}{l}\text { Physiotherapy alone vs physiotherapy plus EMG-BFB } \\
\text { 30-minute sessions 3 times a week for 6 weeks }\end{array}$ \\
\hline Outcomes & $\begin{array}{l}\text { Stride length } \\
\text { Gait cycle time } \\
\text { Angles of knee and ankle during walking }\end{array}$ \\
\hline Notes & Authors' judgement Support for judgement \\
\hline Risk of bias & Unclear risk $\quad$ B - Unclear \\
\hline Bias &
\end{tabular}

Crow 1989

\begin{tabular}{ll}
\hline Methods & $\begin{array}{l}\text { RCT of 6-week duration plus 12-week follow up } \\
\text { Randomisation by a method to balance stratified groups } \\
\text { 3 patients died during the trial, their allocation groups are not stated }\end{array}$ \\
\hline Participants & $\begin{array}{l}40 \text { participants (20 in each group) } \\
\text { Mean age 68 years } \\
\text { Between 2 and 8 weeks poststroke } \\
63 \% \text { male } \\
\text { Residual arm weakness but at least some movement, reasonable cognitive ability }\end{array}$ \\
\hline Interventions & Physiotherapy alone vs physiotherapy plus EMG-BFB \\
\hline Outcomes & $\begin{array}{l}\text { Brunnstrom-Fugl Meyer test } \\
\text { Action Research Arm test }\end{array}$ \\
\hline Notes & \\
\hline Risk of bias & Authors' judgement Support for judgement \\
\hline Bias & High risk - Inadequate \\
\hline Allocation concealment? & \\
\hline
\end{tabular}


Inglis 1984

\begin{tabular}{ll}
\hline Methods & $\begin{array}{l}\text { Cross-over design; data extracted for first intervention period only } \\
\text { Randomisation method not stated }\end{array}$ \\
\hline Participants & $\begin{array}{l}\text { 30 participants (15 in each group) } \\
\text { Mean age } 61 \text { years } \\
\text { Mean time of } 19 \text { months post-stroke } \\
66 \% \text { male }\end{array}$ \\
\hline Interventions & 20 sessions of EMG-BFB plus physiotherapy or physiotherapy alone \\
\hline Outcomes & $\begin{array}{l}\text { Brunnstrom Stages of recovery (raw data not available for active range of motion at the shoulder or Ox- } \\
\text { ford Scale muscle strength scores) }\end{array}$ \\
\hline Notes & \begin{tabular}{l} 
Authors' judgement Support for judgement \\
\hline Risk of bias
\end{tabular} \\
\hline Bias & Unclear risk $\quad$ B - Unclear \\
\hline Allocation concealment? &
\end{tabular}

Intiso 1994

\begin{tabular}{ll}
\hline Methods & $\begin{array}{l}\text { Unclear if the study was truly randomised; randomisation of the patients is not mentioned in the pub- } \\
\text { lished article and so caution should used when interpreting this study } \\
\text { 2-month duration }\end{array}$ \\
\hline Participants & $\begin{array}{l}\text { 16 participants (8 in each group) but } 2 \text { from the control group did not complete the rehabilitation pro- } \\
\text { gram } \\
\text { Mean age } 57 \text { years } \\
\text { Mean time from stroke } 9.8 \text { months }\end{array}$ \\
\hline Interventions & EMG plus physical therapy vs physical therapy alone \\
\hline Outcomes & $\begin{array}{l}\text { Barthel, Canadian, Adams, Basmajian and Ashworth scales used } \\
\text { Stride length and gait speed }\end{array}$ \\
\hline Notes & Authors' judgement Support for judgement \\
\hline Risk of bias & Unclear risk \\
\hline Bias &
\end{tabular}

\section{Lee 1985}

\begin{tabular}{ll}
\hline Methods & RCT of 16-week duration \\
Randomisation method unknown
\end{tabular}

\begin{tabular}{ll}
\hline Participants & 26 participants (13 in each group) \\
Mean age 52 years
\end{tabular}


Lee 1985 (Continued)

Mean time from stroke 5.1 months

$81 \%$ male

\begin{tabular}{|c|c|}
\hline Interventions & Physiotherapy alone vs physiotherapy plus EMG-BFB \\
\hline Outcomes & $\begin{array}{l}\text { Active range of motion at wrist and ankle } \\
\text { EMG potentials }\end{array}$ \\
\hline Notes & \\
\hline Risk of bias & \\
\hline Bias & Authors' judgement Support for judgement \\
\hline Allocation concealment? & Unclear risk \\
\hline
\end{tabular}

\section{Mroczek 1978}

\begin{tabular}{ll}
\hline Methods & $\begin{array}{l}\text { RCT of 4-week duration } \\
\text { Cross-over design; data extracted for first intervention period only } \\
\text { Randomisation method not stated } \\
2 \text { patients with a left-sided hemiplegia were specifically allocated one to each group }\end{array}$ \\
\hline Participants & $\begin{array}{l}\text { 9 participants (5 intervention, } 4 \text { control) } \\
\text { Age range } 50 \text { to } 75 \text { years } \\
\text { Between } 1 \text { and } 10 \text { years post-stroke }\end{array}$ \\
\hline Interventions & EMG plus physical therapy vs physical therapy alone \\
\hline Outcomes & $\begin{array}{l}\text { Active range of motion at wrist } \\
\text { EMG potentials }\end{array}$ \\
\hline Notes & Authors' judgement Support for judgement \\
\hline Risk of bias & High risk $\quad$ Inadequate \\
\hline Allocation concealment? & \\
\hline
\end{tabular}

\section{Mulder 1986}

\begin{tabular}{ll}
\hline Methods & $\begin{array}{l}\text { RCT of 5-week duration } \\
\text { Randomisation method not stated } \\
\text { Assessments by a blinded evaluator }\end{array}$ \\
\hline Participants & 12 participants (6 in each group) \\
& Age range 34 to 68 years \\
& $67 \%$ male \\
& Patients at least 6 months from a stroke event with residual lower limb weakness but able to walk \\
short distances, adequate mental function
\end{tabular}


Mulder 1986 (Continued)

$$
\text { 40-minute sessions } 3 \text { times a week for } 5 \text { weeks }
$$

$\begin{array}{ll}\text { Outcomes } & \text { Active range of movement at ankle joint (but raw data not provided for this outcome measure) } \\ \text { EMG potentials }\end{array}$

Notes

\section{Risk of bias}

\begin{tabular}{lll}
\hline Bias & Authors' judgement & Support for judgement \\
\hline Allocation concealment? & Unclear risk & B - Unclear \\
\hline
\end{tabular}

Smith 1979

\begin{tabular}{ll} 
Methods & $\begin{array}{l}\text { RCT of 6-week duration } \\
\text { Randomisation method not stated } \\
\text { Assessments by a blinded evaluator }\end{array}$ \\
\hline Participants & $\begin{array}{l}11 \text { participants (6 intervention, } 5 \text { control) } \\
\text { Mean age } 52 \text { years } \\
\text { Mean time from stroke } 18 \text { months (1 with subarachnoid haemorrhage) } \\
46 \% \text { male } \\
\text { Patients at least } 6 \text { months from a stroke event with residual lower limb weakness but able to walk } \\
\text { short distances, adequate mental function }\end{array}$
\end{tabular}

\begin{tabular}{ll}
\hline Interventions & Exercise program plus EMG-BFB or exercise alone \\
1-hour sessions twice a week for 6 weeks
\end{tabular}

\begin{tabular}{ll}
\hline Outcomes & Grading score of gait from video analysis \\
Patient questionnaires on perceived sensory and motor function of affected limb
\end{tabular}

$$
\text { Notes }
$$

\section{Risk of bias}

\begin{tabular}{lll}
\hline Bias & Authors' judgement & Support for judgement \\
\hline Allocation concealment? & Unclear risk & B - Unclear \\
\hline
\end{tabular}

ADL: activities of daily living

EMG: electromyograph

EMG-BFB: electromyographic biofeedback

$\mathrm{RCT}$ : randomised controlled trial

vs: versus

Characteristics of excluded studies [ordered by study ID]

\begin{tabular}{ll}
\hline Study & Reason for exclusion \\
\hline Basmajian 1982 & $\begin{array}{l}\text { Insufficient data published in the study to perform analyses } \\
\text { Unable to contact the authors for further data }\end{array}$ \\
\hline
\end{tabular}




\begin{tabular}{|c|c|}
\hline Study & Reason for exclusion \\
\hline Chen 1980 & Insufficient data to extract results from the first stage of the trial (cross-over design) \\
\hline Ince 1987 & $\begin{array}{l}\text { Only ever published as an abstract } \\
\text { Unable to contact the authors for further data }\end{array}$ \\
\hline Ince 1991 & $\begin{array}{l}\text { Unable to obtain copies of articles from the journal 'Medical Psychotherapy' from any library in the } \\
\text { UK }\end{array}$ \\
\hline Mandel 1990 & $\begin{array}{l}\text { Insufficient data published to perform analyses } \\
\text { Unable to obtain further information from authors }\end{array}$ \\
\hline Olney 1997 & $\begin{array}{l}\text { Only ever published as an abstract } \\
\text { Insufficient data available and unclear if EMG-BFB was used in isolation }\end{array}$ \\
\hline Prevo 1982 & $\begin{array}{l}\text { Insufficient data published to allow analysis } \\
\text { Unable to contact the authors for further information }\end{array}$ \\
\hline Shahani 1977 & $\begin{array}{l}\text { Only published as an abstract } \\
\text { Unable to contact the authors for further data }\end{array}$ \\
\hline Taskiran 1993 & $\begin{array}{l}\text { Difficulties with translation from Turkish } \\
\text { Unclear what outcome measures were used }\end{array}$ \\
\hline Wolf 1994 & $\begin{array}{l}\text { Insufficient data published to perform analyses } \\
\text { Unable to contact authors for further information }\end{array}$ \\
\hline
\end{tabular}

EMG-BFB: electromyographic biofeedback

\section{DATA AND ANALYSES}

\section{Comparison 1. Electromyographic biofeedback plus physical therapy versus physical therapy alone}

\begin{tabular}{|c|c|c|c|c|}
\hline Outcome or subgroup title & No. of studies & $\begin{array}{l}\text { No. of partici- } \\
\text { pants }\end{array}$ & Statistical method & Effect size \\
\hline $\begin{array}{l}1 \text { Change in motor strength } \\
\text { (MRC scale) }\end{array}$ & 1 & 22 & Mean Difference (IV, Fixed, 95\% CI) & $1.09[0.48,1.70]$ \\
\hline 2 Change in range of motion & 6 & & $\begin{array}{l}\text { Std. Mean Difference (IV, Fixed, } \\
95 \% \mathrm{Cl})\end{array}$ & Subtotals only \\
\hline 2.1 Ankle joint & 5 & 91 & $\begin{array}{l}\text { Std. Mean Difference (IV, Fixed, } \\
95 \% \mathrm{Cl} \text { ) }\end{array}$ & $0.05[-0.36,0.46]$ \\
\hline 2.2 Shoulder joint & 1 & 26 & $\begin{array}{l}\text { Std. Mean Difference (IV, Fixed, } \\
95 \% \mathrm{Cl})\end{array}$ & $0.88[0.07,1.70]$ \\
\hline 2.3 Knee joint & 1 & 16 & $\begin{array}{l}\text { Std. Mean Difference (IV, Fixed, } \\
95 \% \mathrm{Cl})\end{array}$ & $-0.67[-1.68,0.35]$ \\
\hline 2.4 Wrist joint & 1 & 9 & $\begin{array}{l}\text { Std. Mean Difference (IV, Fixed, } \\
95 \% \mathrm{CI} \text { ) }\end{array}$ & $0.96[-0.48,2.40]$ \\
\hline
\end{tabular}




\begin{tabular}{|c|c|c|c|c|}
\hline Outcome or subgroup title & No. of studies & $\begin{array}{l}\text { No. of partici- } \\
\text { pants }\end{array}$ & Statistical method & Effect size \\
\hline 3 Change in stride length & 4 & & Mean Difference (IV, Fixed, 95\% CI) & Subtotals only \\
\hline $\begin{array}{l}\text { 3.1 Change in number of steps } \\
\text { taken to walk } 6 \text { metres or } 10 \\
\text { metres }\end{array}$ & 2 & 26 & Mean Difference (IV, Fixed, 95\% CI) & $-0.51[-3.27,2.25]$ \\
\hline $\begin{array}{l}3.2 \text { Stride length at end of inter- } \\
\text { vention (metres) }\end{array}$ & 2 & 32 & Mean Difference (IV, Fixed, 95\% CI) & $0.05[-0.08,0.19]$ \\
\hline 4 Change in gait speed & 5 & & $\begin{array}{l}\text { Std. Mean Difference (IV, Fixed, } \\
95 \% \mathrm{CI})\end{array}$ & Subtotals only \\
\hline $\begin{array}{l}\text { 4.1 Change in time taken to } \\
\text { walk a specified distance }\end{array}$ & 3 & 36 & $\begin{array}{l}\text { Std. Mean Difference (IV, Fixed, } \\
95 \% \mathrm{CI})\end{array}$ & $0.13[-0.55,0.80]$ \\
\hline $\begin{array}{l}4.2 \text { Gait cycle time at end of in- } \\
\text { tervention }\end{array}$ & 1 & 16 & $\begin{array}{l}\text { Std. Mean Difference (IV, Fixed, } \\
95 \% \mathrm{CI})\end{array}$ & $-0.81[-1.84,0.23]$ \\
\hline $\begin{array}{l}4.3 \text { Walking velocity }(\mathrm{m} / \mathrm{s}) \text { at } \\
\text { end of intervention }\end{array}$ & 1 & 16 & $\begin{array}{l}\text { Std. Mean Difference (IV, Fixed, } \\
95 \% \mathrm{CI})\end{array}$ & $0.0[-0.98,0.98]$ \\
\hline 5 Changes in functional ability & 6 & & $\begin{array}{l}\text { Std. Mean Difference (IV, Fixed, } \\
95 \% \mathrm{CI})\end{array}$ & Subtotals only \\
\hline $\begin{array}{l}5.1 \text { Change in Brunnstrom } \\
\text { Stages of Recovery score }\end{array}$ & 2 & 57 & $\begin{array}{l}\text { Std. Mean Difference (IV, Fixed, } \\
95 \% \mathrm{CI})\end{array}$ & $0.69[0.15,1.23]$ \\
\hline $\begin{array}{l}\text { 5.2 Change in Brunnstrom-Fugl } \\
\text { Meyer test score }\end{array}$ & 1 & 40 & $\begin{array}{l}\text { Std. Mean Difference (IV, Fixed, } \\
95 \% \mathrm{CI})\end{array}$ & $0.44[-0.19,1.07]$ \\
\hline $\begin{array}{l}\text { 5.3 Upper Extremity Function } \\
\text { test score at end of intervention }\end{array}$ & 1 & 29 & $\begin{array}{l}\text { Std. Mean Difference (IV, Fixed, } \\
95 \% \mathrm{CI})\end{array}$ & $-0.17[-0.90,0.56]$ \\
\hline $\begin{array}{l}5.4 \text { Barthel index score at end of } \\
\text { intervention }\end{array}$ & 1 & 16 & $\begin{array}{l}\text { Std. Mean Difference (IV, Fixed, } \\
95 \% \mathrm{CI})\end{array}$ & $-0.21[-1.20,0.77]$ \\
\hline $\begin{array}{l}5.5 \text { Change in Rivermead Mobili- } \\
\text { ty Index score }\end{array}$ & 1 & 21 & $\begin{array}{l}\text { Std. Mean Difference (IV, Fixed, } \\
95 \% \mathrm{CI})\end{array}$ & $-0.36[-1.24,0.51]$ \\
\hline 6 Change in gait quality score & 2 & & $\begin{array}{l}\text { Std. Mean Difference (IV, Fixed, } \\
95 \% \mathrm{CI})\end{array}$ & Subtotals only \\
\hline $\begin{array}{l}7 \text { Sham EMG-BFB versus no } \\
\text { placebo: range of motion at an- } \\
\text { kle joint }\end{array}$ & 4 & 75 & Mean Difference (IV, Fixed, 95\% CI) & $0.35[-3.27,3.96]$ \\
\hline 7.1 Sham therapy & 1 & 22 & Mean Difference (IV, Fixed, 95\% CI) & $1.72[-7.08,10.52]$ \\
\hline 7.2 No placebo & 3 & 53 & Mean Difference (IV, Fixed, 95\% CI) & $0.07[-3.89,4.03]$ \\
\hline $\begin{array}{l}8 \text { Time from stroke and change } \\
\text { in range of movement at ankle }\end{array}$ & 4 & 75 & Mean Difference (IV, Fixed, 95\% CI) & $0.35[-3.27,3.96]$ \\
\hline 8.1 Less than 6 months & 2 & 43 & Mean Difference (IV, Fixed, 95\% CI) & $1.96[-3.48,7.40]$ \\
\hline
\end{tabular}




\begin{tabular}{lllll}
\hline Outcome or subgroup title & No. of studies & $\begin{array}{l}\text { No. of partici- } \\
\text { pants }\end{array}$ & Statistical method & Effect size \\
\hline 8.2 More than 6 months & 2 & 32 & Mean Difference (IV, Fixed, 95\% Cl) & $-0.92[-5.75,3.90]$ \\
\hline
\end{tabular}

Analysis 1.1. Comparison 1 Electromyographic biofeedback plus physical therapy versus physical therapy alone, Outcome 1 Change in motor strength (MRC scale).

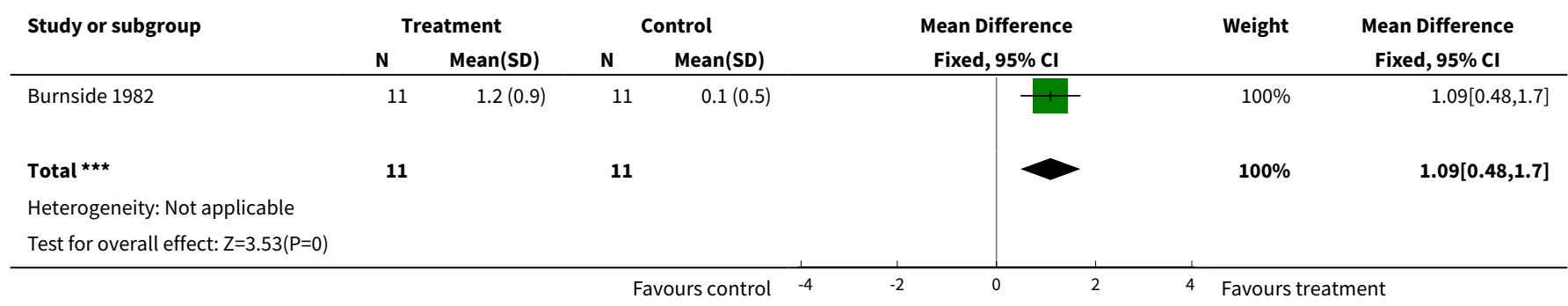

Analysis 1.2. Comparison 1 Electromyographic biofeedback plus physical therapy versus physical therapy alone, Outcome 2 Change in range of motion.

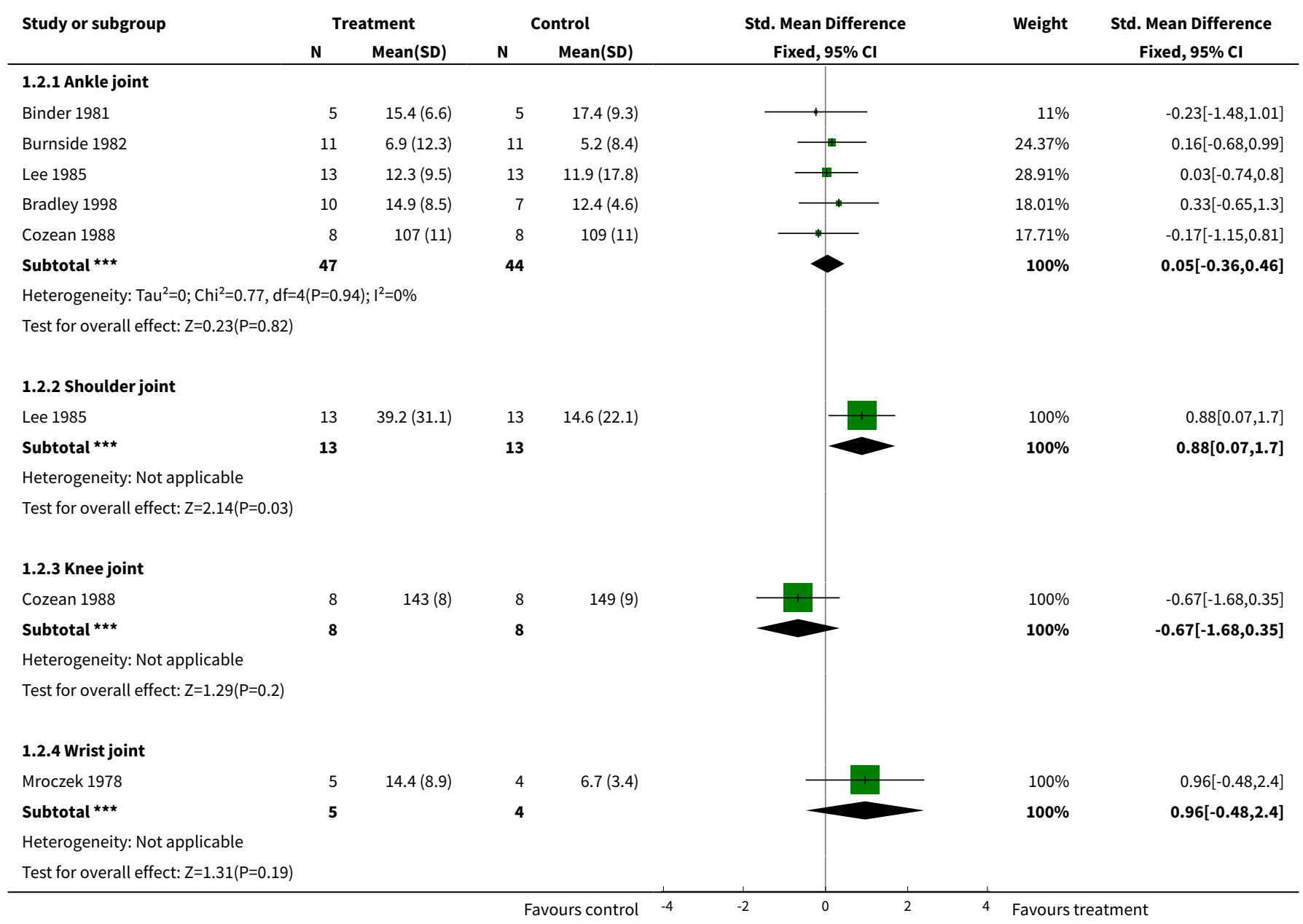




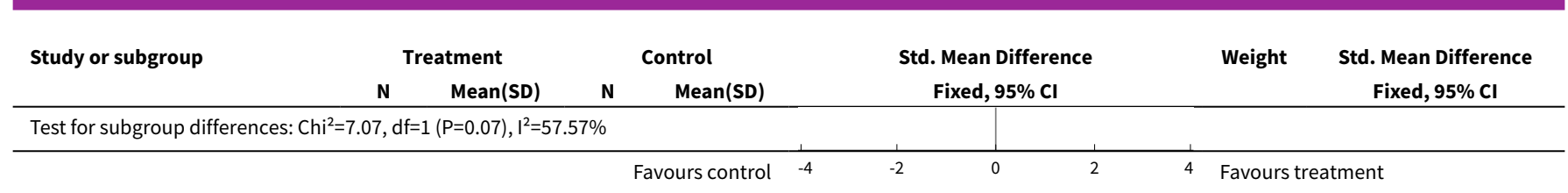

Analysis 1.3. Comparison 1 Electromyographic biofeedback plus physical therapy versus physical therapy alone, Outcome 3 Change in stride length.

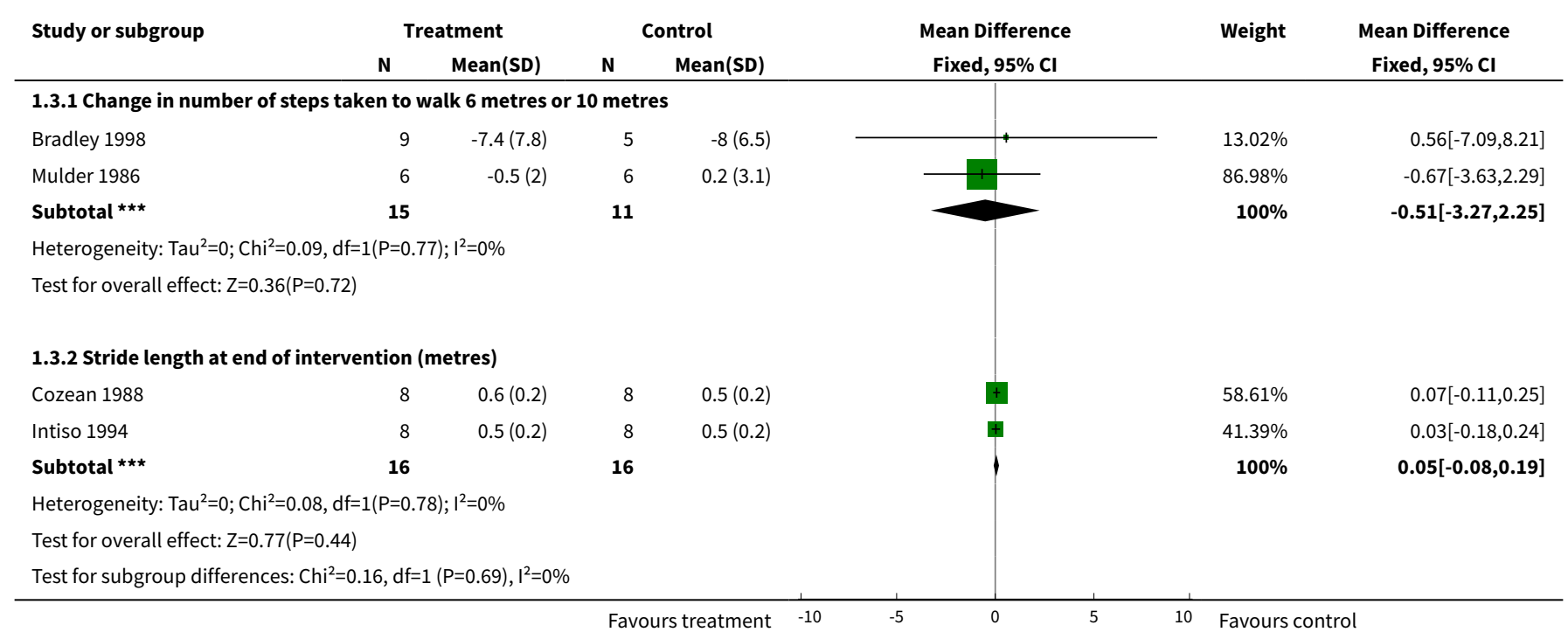

Analysis 1.4. Comparison 1 Electromyographic biofeedback plus physical therapy versus physical therapy alone, Outcome 4 Change in gait speed.

\begin{tabular}{|c|c|c|c|c|c|c|c|}
\hline \multirow[t]{2}{*}{ Study or subgroup } & \multicolumn{2}{|c|}{ Treatment } & \multicolumn{2}{|c|}{ Control } & \multirow{2}{*}{$\begin{array}{c}\text { Std. Mean Difference } \\
\text { Fixed, } 95 \% \mathrm{Cl}\end{array}$} & \multirow[t]{2}{*}{ Weight } & \multirow{2}{*}{$\begin{array}{l}\text { Std. Mean Difference } \\
\text { Fixed, } 95 \% \mathrm{Cl}\end{array}$} \\
\hline & $\mathbf{N}$ & $\operatorname{Mean}(S D)$ & $\mathbf{N}$ & $\operatorname{Mean}(S D)$ & & & \\
\hline \multicolumn{8}{|c|}{ 1.4.1 Change in time taken to walk a specified distance } \\
\hline Binder 1981 & 5 & $18.8(49.6)$ & 5 & $-10.9(17.7)$ & 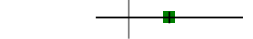 & $26.77 \%$ & $0.72[-0.58,2.02]$ \\
\hline Bradley 1998 & 9 & $-24.4(22.1)$ & 5 & $-18.6(19.5)$ & & $37.71 \%$ & $-0.26[-1.36,0.84]$ \\
\hline Mulder 1986 & 6 & $-2.2(5.1)$ & 6 & $-3.1(13.3)$ & & $35.52 \%$ & $0.09[-1.05,1.22]$ \\
\hline Subtotal ${ }^{\star \star \star}$ & 20 & & 16 & & & $100 \%$ & $0.13[-0.55,0.8]$ \\
\hline \multicolumn{8}{|c|}{ Test for overall effect: $Z=0.37(P=0.71)$} \\
\hline \multicolumn{8}{|c|}{ 1.4.2 Gait cycle time at end of intervention } \\
\hline Cozean 1988 & 8 & $2.3(0.8)$ & 8 & $3.1(1)$ & & $100 \%$ & $-0.81[-1.84,0.23]$ \\
\hline Subtotal $\star \star \star$ & 8 & & 8 & & & $100 \%$ & $-0.81[-1.84,0.23]$ \\
\hline \multicolumn{8}{|c|}{ Heterogeneity: Not applicable } \\
\hline \multicolumn{8}{|c|}{ Test for overall effect: $\mathrm{Z}=1.53(\mathrm{P}=0.13)$} \\
\hline \multicolumn{8}{|c|}{ 1.4.3 Walking velocity $(\mathrm{m} / \mathrm{s})$ at end of intervention } \\
\hline Intiso 1994 & 8 & $0.2(0.1)$ & 8 & $0.2(0.1)$ & & $100 \%$ & $0[-0.98,0.98]$ \\
\hline Subtotal $\star \star \star \star$ & 8 & & 8 & & & $100 \%$ & $0[-0.98,0.98]$ \\
\hline \multicolumn{8}{|c|}{ Heterogeneity: Not applicable } \\
\hline & & & Fav & reatment $\quad-4$ & -2 & 4 Favours C & trol \\
\hline
\end{tabular}




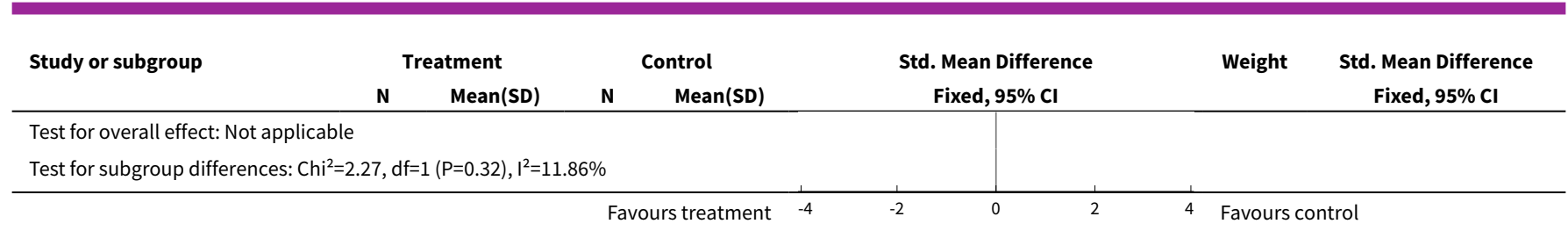

Analysis 1.5. Comparison 1 Electromyographic biofeedback plus physical therapy versus physical therapy alone, Outcome 5 Changes in functional ability.

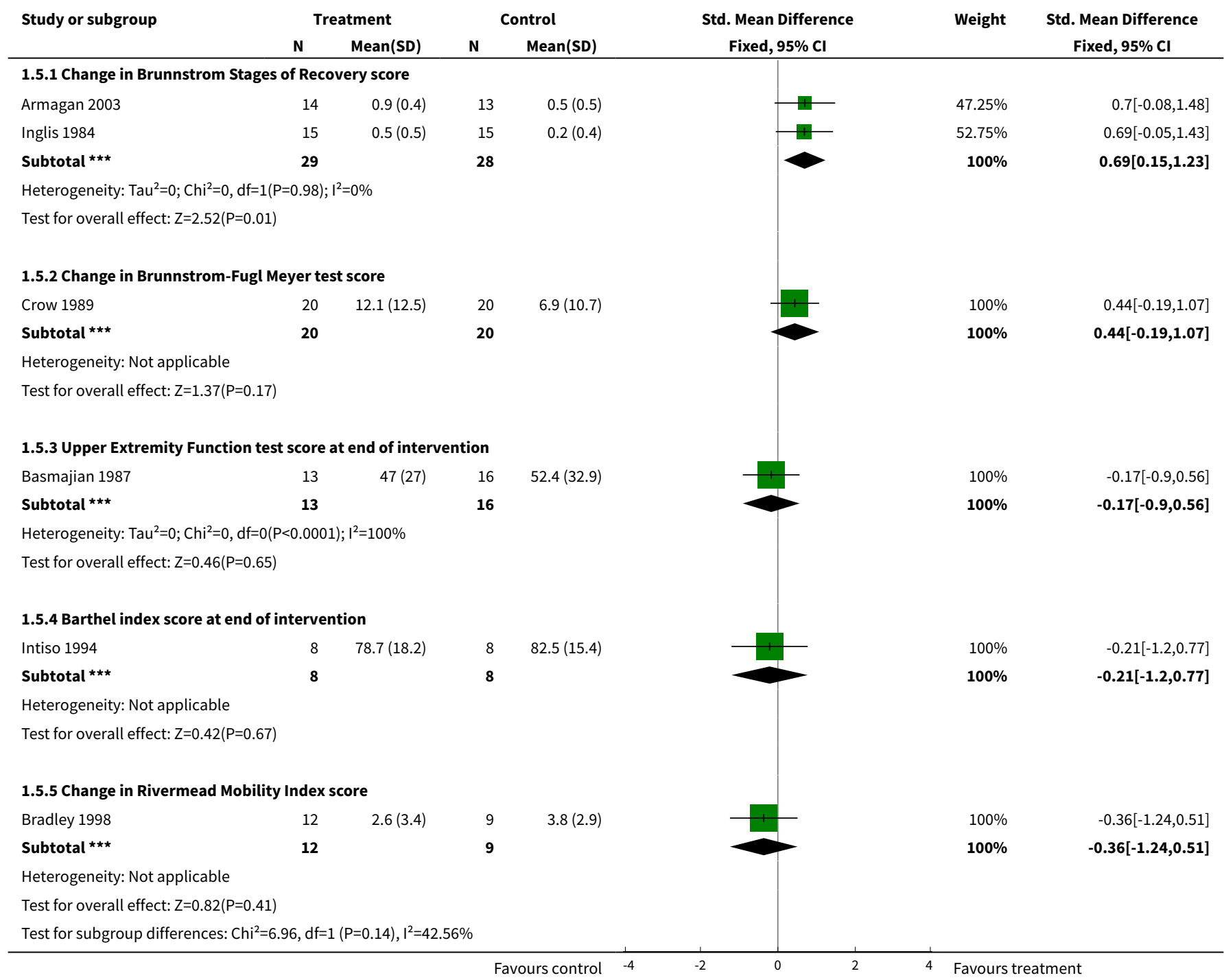


Analysis 1.6. Comparison 1 Electromyographic biofeedback plus physical therapy versus physical therapy alone, Outcome 6 Change in gait quality score.

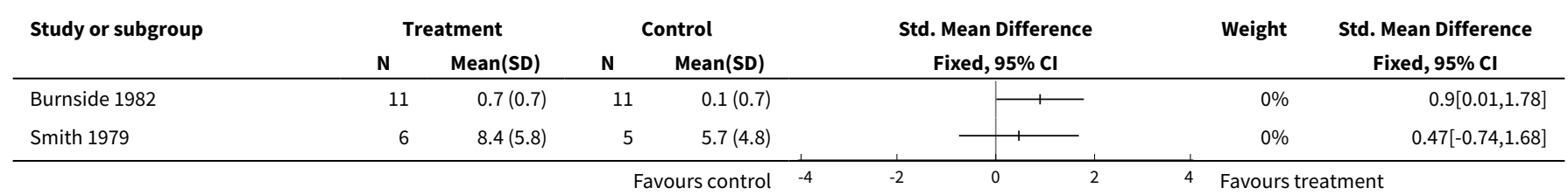

Analysis 1.7. Comparison 1 Electromyographic biofeedback plus physical therapy versus physical therapy alone, Outcome 7 Sham EMG-BFB versus no placebo: range of motion at ankle joint.

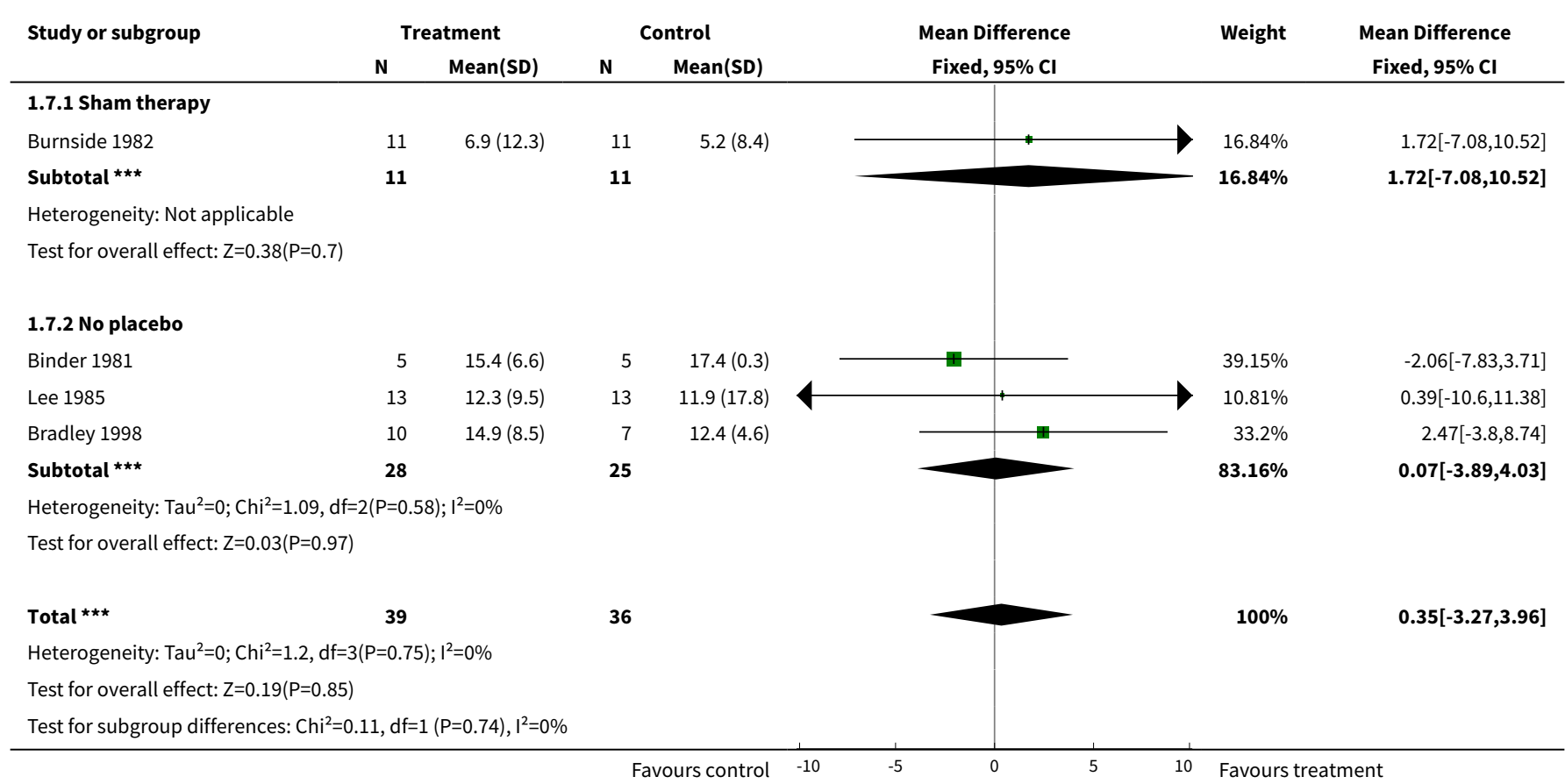

Analysis 1.8. Comparison 1 Electromyographic biofeedback plus physical therapy versus physical therapy alone, Outcome 8 Time from stroke and change in range of movement at ankle.

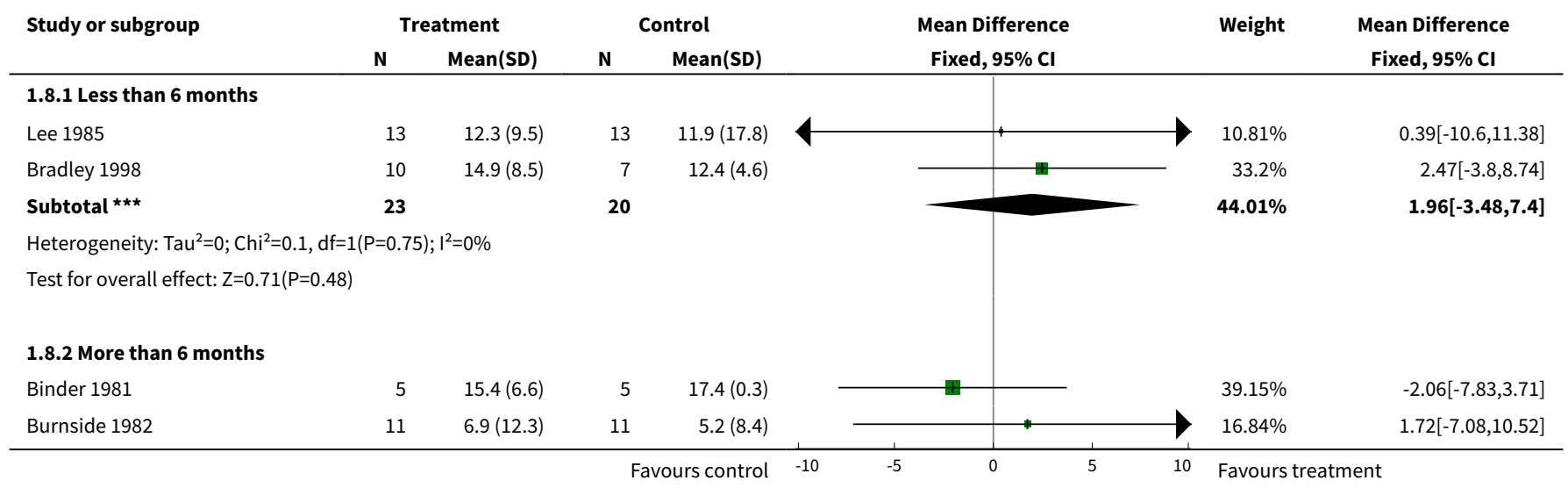




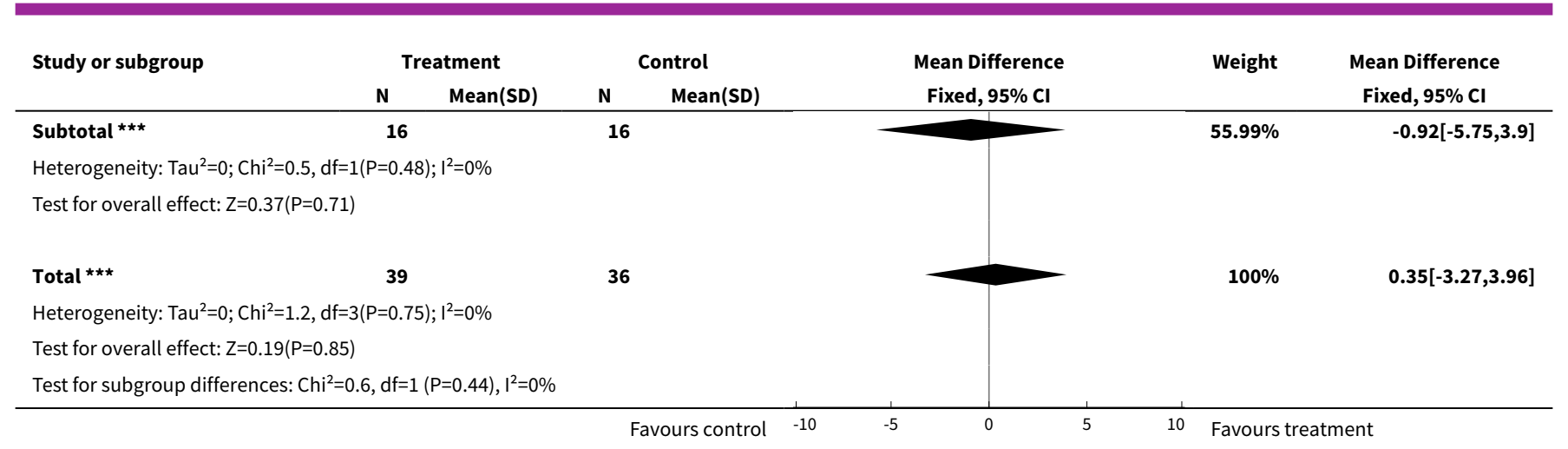

\section{APPENDICES}

\section{Appendix 1. MEDLINE search strategy}

The following strategy was used for MEDLINE and modified for the other databases.

MEDLINE (Ovid)

1. electromyography/

2. "biofeedback (psychology)"/ or feedback/ or feedback, psychological/

3. (electromyograph\$ or electromyogram\$ or EMG\$).tw.

4. (biofeedback or feedback).tw.

5. 1 or 2 or 3 or 4

6. cerebrovascular disorders/ or exp basal ganglia cerebrovascular disease/ or exp brain ischemia/ or exp carotid artery diseases/ or exp cerebrovascular accident/ or exp hypoxia-ischemia, brain/ or exp intracranial artery diseases/ or exp "intracranial embolism and thrombosis"/ or exp intracranial hemorrhages/

7. (stroke or poststroke or cerebrovasc $\$$ or cerebral vasc\$ or cva\$).tw.

8. ((cerebral or cerebellar or brain\$ or vertebrobasilar) adj5 (infarct\$ or isch?emi\$ or thrombo $\$$ or emboli\$ or apoplexy)).tw.

9. ((cerebral or brain $\$$ or subarachnoid) adj5 (haemorrhage or hemorrhage or haematoma or hematoma or bleed\$)).tw.

10. hemiplegia/ or (hemipleg\$ or hemipar\$).tw.

11.6 or 7 or 8 or 9 or 10

12.5 and 11

13. limit 12 to human

14. cerebrovascular disorders/rh or exp basal ganglia cerebrovascular disease/rh or exp brain ischemia/rh or exp carotid artery diseases/rh or exp cerebrovascular accident/rh or exp hypoxia-ischemia, brain/rh or exp intracranial arterial diseases/rh or exp "intracranial embolism and thrombosis"/rh or exp intracranial hemorrhages/rh

15. hemiplegia/ or paresis/rh

16. 14 or 15

17.5 and 16

18. exp rehabilitation/

19. motor activity/ or movement/ or range of motion, articular/

20. recovery of function/ or disability evaluation/ or muscle weakness/

21. gait/ or locomotion/ or walking/

22. (recovery or motor function or gait or ambulation or muscle weakness or muscle power or movement or mobility).tw.

23. 18 or 19 or 20 or 21 or 22

24. 13 and 23

25. 17 or 24

WHAT'S NEW

\begin{tabular}{lll}
\hline Date & Event & Description \\
\hline 19 August 2008 & Amended & Converted to new review format. \\
\hline
\end{tabular}




\section{CONTRIBUTIONS OF AUTHORS}

Initial literature search and wording of the background by Henry Woodford. Guidance and feedback comments provided by Christopher Price. Study articles reviewed by both authors.

\section{DECLARATIONS OF INTEREST}

None known

\section{N D X T ERM S}

\section{Medical Subject Headings (MeSH)}

${ }^{\star}$ Recovery of Function; *Stroke Rehabilitation; Biofeedback, Psychology [ ${ }^{*}$ methods]; Electromyography [ ${ }^{\star}$ methods]; Motor Skills; Randomized Controlled Trials as Topic; Stroke [physiopathology]

\section{MeSH check words}

Humans 